\title{
COMPUTER-AIDED INSTRUCTION AS A PART OF AN UNDERGRADUATE PROGRAMME IN ANAESTHESIA
}

\author{
J.W.R. MCINTYRE
}

ABSTRACT

\begin{abstract}
Medical students should learn certain facts and comprehension of these facts during an elective month spent in a Department of Anaesthesia. This enables them to make the most of the tutorial situation in which they work with clinical anaesthetists. Pre- and post-elective multiple choice questions were used to test the efficacy of computer based non-linear programmes of multiple choice questions and explanations in adding to the students' knowlcdge. They were associated with an improvement in student performance and were acceptable to students and instructors. However, computer based instruction should only be used to improve certain learning situations and should not be employed as an alternative to interaction with physicians and patients.
\end{abstract}

ANALSTHLTISTS are important to medical students because they can impart important information and skills relevant to many aspects of patient care. Medical students are important to anaesthetists because recruits to the specialty come ultimately from their ranks. Possibly the deciding factors for a physician adopting anaesthesia as a specialty are interest in its academic aspects and compatibility of practise with personal interest.' Thus a period of time spent in a Department of Anaesthesia can be a valuable learning experience, and an opportunity to present the specialty in a realistic and attractive light.

The objectives of an elective period can be presented in a variety of ways ${ }^{2-6}$ such as learning objectives, educational goals and lists of skills and knowledge to be acquired. The general objectives of the anaesthesia elective in this institution are that the student should acquire and comprehend certain factual knowledge and its application, as well as acquiring certain motor skills. Above all, a curiosity about patient care related to the specialty and problems as yet unsolved should be instilled. Acting as a teacher while doing clinical work, the anaesthetist serves in a tutorial capacity and greater use can be made of the anaesthetist's knowledge, if emphasis can be placed on the application of factual knowledge, rather than teaching the facts and their comprehension. The objectives that are the principal subject of the project reported here are teaching

J.W.R. McIntyre, M.R.C.S., L.R.C.P., F.F.A. R.C.S., F.R.C.P.(C). Professor, Department of Anaesthesia, University of Alberta Hospital, Edmonton, Alberta. This project was financially supported by the Gladys \& Merrill Muttart Foundation. the students facts and comprehension of these facts. These are categories (1) and (2) of Bloom's taxonomy of educational objectives ${ }^{7}$ (Table I).

The method for attaining these two objectives needed to have certain characteristics. It should ensure that each student was exposed to the facts and explanation of these facts considered essential for the student, require student participation, divide learning time into brief intermittent periods of activity, help faculty to make the most effective use of the time spent with medical students, and permit analysis of student responses.

Instructional methods and materials have been reviewed by McCardle. ${ }^{8}$ She stated that selection of the appropriate methods of instruction required an instructor to make a number of decisions that usually resulted from answers to the following questions:

1. Who or what is to carry most of the responsibility for presenting the instruction - the instructor, the materials, or both?

2. Given the assignment of responsibility for instruction, what effect will this have on the number of methods the instructor can use during the session of his course?

3. How will decisions to the first two questions be facilitated, limited, or modified by administrative, student, or environmental constraints?

The methods of instruction described were classified under principal headings of group instruction and individualized instruction. The instructional materials included video tape, audio tape, motion pictures, $35 \mathrm{~mm}$ slides and computer based storage and presentation. 
TABLE I

Taxonumy of Educational Objectives

\begin{tabular}{ll}
\hline 1. Knowledge & $\begin{array}{l}\text { The recall of specific and isolable bits of } \\
\text { information. }\end{array}$ \\
2. Comprehension & $\begin{array}{l}\text { A type of understanding or apprehension such that } \\
\text { the individual knows what is being communicated } \\
\text { and can make use of the material or idea being } \\
\text { communicated without necessarily relating it to } \\
\text { other material or seeing its fullest implications. }\end{array}$ \\
3. Application & $\begin{array}{l}\text { The use of abstractions in particular and concrete } \\
\text { situations. }\end{array}$ \\
4. Analyses & $\begin{array}{l}\text { The breakdown of communication into its constituent } \\
\text { elements or parts such that the relative hierarchy of } \\
\text { ideas is made clear and/or the relations between the } \\
\text { ideas are made explicit. }\end{array}$ \\
The putting together of elements and parts so as \\
to form a whole.
\end{tabular}

Individual computer based instruction appeared best to satisfy the needs for this particular teaching situation. The method selected for testing was exposure of students to programmes of multiple choice questions, each question followed by an explanation and literature reference. Each multiple choice question was conventional and the ensuing explanation consisted of approximately 120 words. Fifteen programmes were constructed - anatomy (2), physiology (2), pharmacology (3), equipment (2), medical problems (2), anaesthetic complications (1), obstetrical analgesia (1), obstetrical anaesthesia (1), cardiopulmonary resuscitation (1). Guidelines to the content of the programmes appear in Tables 11 and III. Each programme consisted of 25 to 30 questions and explanations. The sophistication of information presented was that believed necessary for family practitioners receiving six months' basic training in anaesthesia before receiving privileges to give anaesthetics for simple procedures in small rural hospitals in Alberta. The questions in each programme did not combine to form a single sequence about the major topic of that programme. In other words they did not constitute linear programmed instruction. Linear programmes are most appropriate for instruction when the objectives together constitute a series of progressive steps. They are not suitable when course objectives require the use of references or when attitudinal and problem solving instructional objectives have been developed. Thus it appeared that presenting a series of isolated questions about a similar topic would be more effective in stimulating the student's curiosity and the tutorial situation in the anaesthetist's working milieu. The information was programmed for presentation at a computer terminal, the data base being the University Computing Centre.

At this medical school students in their third year may spend a month with clinical anaesthetists at any one of five hospitals in the city, and at one of them the group of students had access to a dedicated computer terminal. Each student in that group had a personal sign-on number and could do the series of programmes only once and in the absence of any other student. The student proceeded through a programme at his own speed. The response to a question was followed by the explanation, the reference, and then, at the student's request, the next question.

The success of the instructional method in achieving its objectives was tested by pre- and post-elcctive multiple choice question examinations consisting of 130 questions and by opinions solicited from students and faculty. The examinations before and after the programme were the same. All the students gathered in the same place to do them under strict surveillance. The project developed in phases.

Phase I - The first phase lasted three months and began during the latter part of an academic year. Its purpose was to accustom the student body to the new organization in the elective. At that time a brief outline of the objectives for the elective were distributed to students and staff. It comprised a core curriculum presented in 50 headings and a recommended reading list of books. 
TABLE II

\begin{tabular}{ll}
\hline \hline Anatomy & \\
$\begin{array}{l}\text { Endotracheal intubation } \\
\text { Extradural anaesthesia }\end{array}$ & $\begin{array}{l}\text { Posture during surgery } \\
\text { Venipuncture } \\
\text { Spinal anaesthesia }\end{array}$ \\
Brachial plexus block & Abnormal location of arteries \\
Physiology & \\
Respiration & \\
Cardiopulmonary function & Effects of posture \\
Oxygen transport & Reflexes stimulated by surgery \\
Gastric emptying & Intermittent positive pressure ventilation \\
Pain & Obesity \\
Intracranial presure & Temperature control \\
Blood & Autonomic nervous system \\
Pharmacology & Renal function \\
General anaesthetic agents & Narcotics \\
Local anaesthetic agents & Hypnotics \\
Cardiovascular drugs & Analgesics \\
C.N.S. stimulants & Tranquilizers \\
Drugs acting at synaptic and neuroeffector junctional sites. \\
Medications interacting with drugs associated with anaesthetic practice. \\
Equipment
\end{tabular}

TABLE III

\begin{tabular}{|c|c|}
\hline \multicolumn{2}{|c|}{ Medical problems and anaesthesia } \\
\hline $\begin{array}{l}\text { Myocardial disease } \\
\text { Renal dysfunction } \\
\text { Liver disease } \\
\text { Thyroid disease } \\
\text { Muscle disease } \\
\text { Diabctcs mellitus }\end{array}$ & $\begin{array}{l}\text { Adrenal disease } \\
\text { Alcoholism } \\
\text { Spinal cord transection } \\
\text { Burns } \\
\text { Blood disease } \\
\text { Respiratory dysfunction }\end{array}$ \\
\hline \multicolumn{2}{|c|}{$\begin{array}{l}\text { Maternal physiological changes during pregnancy } \\
\text { Placental transfer of drugs } \\
\text { Drug effects on fetus and neonate } \\
\text { Pain pathways during labour and delivery } \\
\text { Analgesia during labour } \\
\text { Fetal monitoring during labour } \\
\text { Anaesthetic drugs and uterine function } \\
\text { Neonatal resuscitation }\end{array}$} \\
\hline \multicolumn{2}{|l|}{$\begin{array}{l}\text { Artificial ventilation } \\
\text { External cardiac compression } \\
\text { Heimlich's manoeuvre } \\
\text { Drugs used during C.P.R. }\end{array}$} \\
\hline \multicolumn{2}{|l|}{ Complications of anaesthesia } \\
\hline $\begin{array}{l}\text { Hypoxemia } \\
\text { Tracheal trauma } \\
\text { Pneumothorax } \\
\text { Atelectasis } \\
\text { Distension of air-containing } \\
\text { cavities }\end{array}$ & $\begin{array}{l}\text { Post lumbar puncture headache } \\
\text { Peripheral neuropathy } \\
\text { Hypothermia } \\
\text { Pulmonary edema } \\
\text { Embolism }\end{array}$ \\
\hline
\end{tabular}


TABLE IV

Project Phast 2

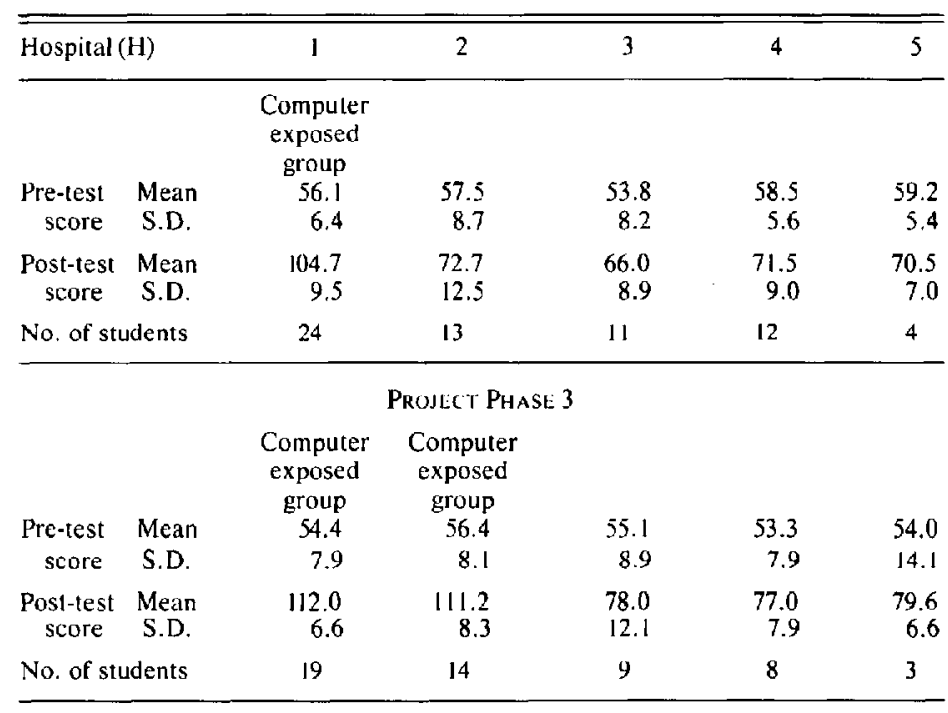

Phase 2 - The second phase took place during the following academic year and in detail was similar to Phase 1.

Phase 3 - The third phase took place during the succeeding academic year. The objective was to discover whether access to the programmes for students in a second hospital was associated with an improvement in their post-elective examination scores. The terminal in the original hospital remained in position and another terminal was placed in another hospital. In other respects arrangements remained the same except that a booklet outlining the core curriculum, consisting of 265 items expressed as single sentence questions with references, was distributed to each student and faculty member. This material closely followed the questions presented in the computer based programmes.

The results of the multiple choice question examinations in Phases 2 and 3 are shown in Table IV. The results of statistical analysis of the original data are shown in Table $V$. The results of Phases 2 and 3 are as follows, statistical support being shown in Table IV. There were no significant differences in the pre-elective test scores of students between the different hospitals. There was a significant difference in the post-elective scores between all student groups who had access to the computer programmes and those who did not. The students exposed to the computer performed better. The comprehensive booklet used in Phase 3 was associated with a
TABLE V

Mean Souares From ANalysis of Variance

\begin{tabular}{lrcc}
\hline Source & d.f. & $\begin{array}{c}\text { Pre-elective } \\
\text { test }\end{array}$ & $\begin{array}{c}\text { Post-elective } \\
\text { test }\end{array}$ \\
\hline $\begin{array}{l}\text { Computer } \\
\quad \text { exposed (C) }\end{array}$ & 1 & 6.39 & $476^{*}$ \\
Booklet & & & \\
$\quad \begin{array}{l}\text { exposed (B) } \\
\text { Hospital (H) }\end{array}$ & 1 & 82.31 & $1451^{*}$ \\
$\mathrm{C} \times \mathrm{B}$ & 4 & 32.70 & 51 \\
$\mathrm{~B} \times \mathrm{H}$ & 1 & 2.17 & 5 \\
Error & 2 & 46.62 & 52 \\
\hline
\end{tabular}

*Significant at the $0.1 \%$ probability. Intcraction between the effect of computer exposure and booklet, and booklet and hospital is referred to as $\mathrm{C} \times \mathrm{B}$, and $\mathrm{B} \times \mathrm{H}$

significant improvement in the post-elective scores, in comparison with the groups of students in Phase 2, none of whom had the booklet.

Staff anaesthetists were generally in favour of the programmes, because many believed that the students became knowledgable more quickly and they felt freer to pursue any topic in the operating room that they felt inclined to. The programmes were popular with the students. Indeed half way through Phase 2, discontinuation of the programmes resulted in a small student meeting that declared the cessation an unethical experiment because they were being denied something they believed to be of educational value.

There are many ill-defined processes as- 
sociated with learning in a medical school and certainly students perform better if they and their teachers have a clear concept of what they should learn. It seems very likely that the published guide played a part in the improvement of all the groups in Phase 3, although this improvement was small. Access to the computer programmes was associated with a marked improvement, however.

Other factors that may have been influential include alterations in student attitude and progressive diffusion of knowledge from other areas of instruction in the medical school, altering the conditions during which Phase 2 and Phase 3 were conducted. Bruhn, et al. ${ }^{9}$ found little difference between the performance of students who had and who had not done an elective in anaesthesia. The testing of the students in their group appears to have been less rigorous than in the study reported here. However, meetings devoted to critical care medicine, intensive care and related specialist groups indicate very clearly that there are many similarities between the operating room practise of anaesthetists and the clinical work of physicians not designated anaesthetists. Basic science departments such as physiology and pharmacology, in an endeavour to motivate their students also find it useful to employ theoretical clinical examples for their teaching. Thus it may be that a progressive increase in knowledge of topics related to anaesthesia will be occurring in the student body regardless of time spent doing an elective in anaesthesia. Such statements should not be interpreted as a reason for discontinuing - or not starting - an elective in anaesthesia. Rather they are reasons for developing a cohesive elective programme, so that each student is exposed to a fund of knowledge basic to the specialty which clearly indicates the background necessary to produce the troublefree anaesthesia they see so often; and to draw their attention to problems which make anaesthesia a challenging discipline both practically and academically.

At this point in is important to stress the fact that this computer aided instructional system was set up to solve specific problems, and among these was the need to provide certain knowledge necessary for the understanding of other things to be learned during the elective. Another objective was to make a contribution to long term organized knowledge that the student could utilize under future circumstances. It is considered most important that these programmes are done during the elective period spent in clinical anaesthesia, because the student can perceive the significance of the factual material.

The benefits of other types of computer aided instruction under different circumstances have been described elsewhere, ${ }^{10}$ but there is a real hazard of reduction of time spent with clinicians in the clinical milieu, the student or teacher believing that computer based instruction is necessarily better or more pleasant. Discussion with a skilled clinician in the working environment can have a variety unlikely to be matched by any computer programme and can be correlated with clinical situations virtually impossible to reproduce exactly in simulations. The students should also experience the social interactions with which it is necessary to come to terms if they give the specialty serious consideration. Thus access to and design of computerized programmes for use during an anaesthesia elective should be carefully planned before they are incorporated in a teaching plan.

In conclusion, the results described strongly support the idea that computer aided instruction of the kind described benefits students doing an elective in anaesthesia and the clinical anaesthetists teaching them. Further investigation is planned to confirm the need for such computer aided instruction, if optimum student performance following an elective in anaesthesia is to be attained in the existing teaching environment.

\section{ACKNOWLEDGEMENTS}

R. von Kuster, B.Comm., Senior Programmer Analyst, R.S. McLaughlin Examination Research Centre. Brian Pinchbeck, Statistical Analyst, Computing Services, University of Alberta.

\section{REFERENCES}

1. BruhN. J.G. Specialty choices of medical graduates taking anesthesiology preceptorships: a follow-up study. Anesthesiology 41: 270 (1974).

2. Fisk. G.C. Objectives for undergraduate education in resuscitation and anaesthesia for children. Anaesth. \& Int. Care 3: 312 (1975).

3. Editorial, Hunter, A.R. Some thoughts on the education of anaesthetists. Br. J. Anaesth. 47:1121 (1975).

4. Paull. JohN D. Organizing an educational exercise. Anaesth. \& Int. Care 4: 297 (1976).

5. ZiNDleR. MARTIN. Undergraduate training in anaesthesia, resuscitation and acute medicine. Int. Anesthesiol. Clinics 14: 562 (1976).

6. JACK, R.D. Leaming objectives and educational goals. Br. J. Anaesth. 47: 1122 (1975). 
7. BLoom, B.S. Taxonomy of educational objectives. Longmans' Green \& Co., London (1956).

8. MC Cardle, Patricia J. Instructional methods and materials. Int. Anesthesiol. Clinics 14:33 (1976).

9. Bruhn, John G., Epstein, Burton S. \& BurNAP. THOMmas K. Senior medical students' knowl- edge and attitudes toward anesthesiology in ten medical schools. Anesthesiol. 39: 95 (1973)

10. Rubin. Martin L., Knetsch, Marilyn \& ROSENBLATT. Richard. National Library of Medicine, Betheseda, M.D., U.S.A. Evaluation of biomedical computer assisted instruction from a user/institutional viewpoint.

\section{RÉSUMÉ}

Certaines questions doivent être retenues et compris par les étudiants en médecine lors d'un stage facultatif dans un département d'anesthésie et c'est ce qui leur permet de tirer profit de cette expérience qui les met en contact avec leurs tuteurs anesthésistes cliniciens. Un questionnaire à choix multiples avant et après le stage a été utilisé pour évaluer l'efficacité de programme informatisé de questions à choix multiples complété par des explications pertinentes. La méthode a été acceptée facilement aussi bien par les étudiants que leurs moniteurs et accompagnée d'une amélioration dans la performance des étudiants. Cependant, l'enseignement par ordinateur ne devrait être utilisé que dans certaines situations spécifiques et non comme une alternative à l'expérience fournie par l'interraction entre patients et médecins. 